Б. Т. Кононов, Ю. Д. Мусаїрова

Харківський національний університет Повітряних Сил імені Івана Кожедуба, Харків, Україна

\title{
ШЛЯХИ ПЈДВИЩЕННЯ ДОСТОВІРНОСТІ ОЦІНЮВАННЯ ТЕХНІЧНОГО СТАНУ ОКРЕМИХ ЦИЛІНДРІВ БАГАТОЦИЛІНДРОВИХ ДИЗЕЛЬНИХ ТА БЕНЗИНОВИХ ДВИГУНІВ
}

\begin{abstract}
Наводяться рекомендації щодо підвищення достовірності оцінювання загального технічного стану дизельних та бензинових двигунів внутрішнього згоряння електроагрегатів військових електростанції при використанні в якості діагностичного параметри коефіцієнта корисної дії або питомого розходу палива. Основна увага приділяється способам оцінювання технічного стану окремих циліндрів багатоциліндрових двигунів. Пропонується при оцінюванні ступеня нерівномірності роботи циліндрів двигуна в якості діагностичного параметра використовувати ступінь нерівномірності кутової частоти обертання його вала, пояснюється, як слід вимірювати цю величину, вказується, що на достовірність результатів вимірювань впливають крутильні коливання пружної системи «колінчатий вал - циліндро-поршнева група». Наводяться варіанти технічних рішень, використання яких дозволить усунути вплив крутильних коливань на результати діагностування. Визначено, що дієвим засобом врахування крутильних коливань пружної системи «колінчатий вал - циліндро-поршнева група» при визначенні ступеня нерівномірності частоти обертання вала $\epsilon$ використання змінної частоти генерування імпульсів, за допомогою яких здійснюють визначення часу повороту вала на зазначений кут, або визначення кута між спалахами в сусідніх за порядком роботи циліндрів за допомогою індикатора моменту вприскування палива в циліндр двигуна та датчика верхньої мертвої точки.

Ключов і слов а : діагностичні параметри для оцінювання загального технічного стану двигуна та оцінювання технічного стану окремих циліндрів, ступінь нерівномірності частоти обертання вала, крутильні коливання та їх вплив на результати визначення ступеня нерівномірності роботи окремих циліндрів.
\end{abstract}

\section{Вступ}

Постановка проблеми. Забезпечення безвідмовності автономних та резервних джерел електричної енергії, які працюють в системах електропостачання комплексів озброєння і військової техніки, досягається своєчасним проведенням регламенту i ремонту їх окремих вузлів та систем. В теперішній час, як правило, періодичність виконання регламентних робіт і ї обсяг визначаються статистичними даними щодо зниження працездатності тих чи інших типів дизельних або бензинових агрегатів. Зазначений підхід до проведення регламенту не враховує дійсний технічний стан агрегату, призводить до зайвих матеріальних і часових втрат, знижує надійність військових електростанцій, оскільки не виключає їх несподіваної відмови.

Ступінь достовірності визначення дійсного технічного стану військової електростанції залежить від того як повно та чи інші контролюємі параметри відображають фактичний стан об'єкту контроля. Кількість таких параметрів повинна бути достатньою для визначення фактичного технічного стану військового електроагрегата, а власне діагностичні параметри повинні давати відповідь щодо ефективності процесів перетворення енергії, якості виробляємої електричної енергії й стану механічно спряжених вузлів та деталей. 3'ясувати, які параметри слід віднести до діагностичних параметрів можливо, якщо представити військовий електроагрегат як об'єкт діагностики в вигляді деякої складної системи, яка складається 3 послідовно та паралельно з'єднаних ланок. До таких ланок слід віднести регулятор частоти обертання, систему паливоподачі, циліндро - поршневу групу, яка складається з і-циліндрів, з'єднаних паралельно, колінчатий вал, синхронний генератор 3 системою збудження. Між окремими послідовно з'єднаними ланками можливо встановити функціональні зв'язки між їх вхідними та вихідними параметрами , наприклад, для системи паливоподачі залежність

$$
F_{1}=f\left(n, g_{Ц I}\right)
$$

де $n$ - частота обертання вала; $g_{Ц I}$ - циклова подача палива в і-му циліндрі.

Для циліндро-поршневої групи, колінчатого вала та генератора слід встановити такі залежності

$$
\begin{aligned}
& F_{2}=f\left(g_{Ц I}, N_{i}\right) ; \\
& F_{3}=f\left(N_{i}, N_{m}\right) ; \\
& F_{4}=f\left(N_{m}, P_{a}\right),
\end{aligned}
$$

де $N_{i}$ - індикаторна потужність і-го циліндра; $N_{m}$ механічна потужність на валу; $P_{a}$ - активна потужність на виході генератора.

Узагальнюючими параметрами, які дозволяють здійснити оцінювання вдосконаленості процесу перетворення енергії є часові витрати палива $G_{n}$ (вхідний параметр) та активна потужність $P_{a}$ (вихідний параметр). Таким чином, в якості узагальнюючого діагностичного параметра, за допомогою якого можливо здійснювати оцінювання загального технічного стану військового агрегата можливо використовувати коефіцієнт корисної дії

$$
\eta=\frac{P_{a}}{H_{n} G_{n}},
$$

де $H_{n}$ - теплотворна властивість палива. 
В якості діагностичного параметру для оцінювання загального технічного стану також можливо використовувати питомі втрати палива $g$, які визначаються при постійних значеннях виробляємої напруги $U=$ const i ïi частоти $f=$ const.

Наявність паралельних ланок вимагає здійснення окремої оцінки їх технічного стану, як і оцінки технічного стану механічно спряжених деталей й оцінки технічного стану систем двигуна, таких як змащення, охолодження, газорозподілу тощо.

Для оцінювання технічного стану механічно спряжених деталей можливо використовувати віброакустичні методи або методи, засновані на визначенні змінення маси $\Delta m$ чи геометричних розмірів $\Delta \ell$ діагностуємих деталей. Крім того, часто використовують методи, засновані на виявленні в рідині, що змащує, металевих частинок, які вказують на підвищений знос тих чи інших вузлів електроагрегатів. Віброакустичні методи діагностики базуються на проведенні спектрального аналізу пружних коливань, що виникають при взаємодії спряжених деталей в момент зміни напряму їх руху. При цьому при зміні частоти віброакустичного сигналу визначають джерело сигналу (вузол, який зношується), а по потужності сигналу (інтенсивності) визначають ступінь зносу вузла. Стан окремих систем електроагрегата оцінюють, використовуючи такі параметри як тиск, температура та витрати речовин, які використовуються в цих системах, а саме в системах охолодження, змащення, підготовки палива. Стан систем підготовки повітря та газовихлопу оцінюють по механічному забрудненню фільтруючих елементів та визначенню продуктів неповного згоряння палива (визначенню таких величин, як $\mathrm{CO}, \mathrm{S}$ ) в системі газовихлопу. Стан системи газорозподілу, частіше за все, визначають, використовуючи віброакустичні методи. Технічний стан генератора звичайно визначають шляхом вимірювання величини опору ізоляції його струмоведучих частин відносно корпуса, стан його механічно спряжених деталей визначають таким же способом як і стан таких же деталей власне привідного двигуна.

При визначенні технічного складу паралельно з'єднаних ланок доцільно порівнювати показники їх роботи. При цьому найбільш складно здійснювати оцінювання технічного стану циліндро-поршневої групи, де для оцінювання, частіше за все, використовують ступінь нерівномірності розподілу навантаження між окремими циліндрами

$$
\delta_{i}=\frac{x_{i}-x_{c p}}{x_{c p}},
$$

де $x_{i}$ - параметр робочого процеса в і-му циліндрі; $x_{c p}$ - середнє значення параметра.

До параметрів, які можливо використовувати для оцінювання якості протікання робочих процесів в циліндрі слід віднести циліндрові індикаторні потужності $N_{i}$, середній індикарний тиск $P_{i}$, максимальний тиск в процесі стискування $P_{\operatorname{maxc}}$ і максималь- ний тиск в процесі згоряння $P_{\max }$, середній інтегральний тиск $P_{t}$, температура відпрацювавших газів $T_{2 i}$, миттєве значення частоти обертання валу $n_{i}$, що відповідає такту робочого ходу в і-му циліндрі.

Використання такого параметра як циліндрова індикаторна потужність $N_{i}$ дозволяє здійснювати пряме оцінювання технічного стану окремих циліндрів двигуна. Решта параметрів використовуються для непрямих оцінок технічного стану циліндрів двигуна.

Суттєвою проблемою при оцінюванні технічного стану окремих циліндрів 3 використанням зазначених параметрів є проблема достовірності результатів вимірювань. Так, при використанні такого параметра як величина індикаторної потужності $N_{i}$ необхідно зняти індикаторну діаграму, здійснити іiі обробку та використовувати при цьому для вимірювання середнього індикаторного тиску пристрій, який повинен містити у своєму складі перетворювач тиску і положення поршня 3 координат « тиск Р час $t$ » в координати « тиск $\mathrm{P}$ - об'єм V». Точність вимірювання залежить від точності прив'язки індикаторної діаграми до верхньої мертвої точки в контролюємому циліндрі двигуна. При використанні в якості діагностичних параметрів значень тиску або температури на результати вимірювань суттєво впливає місце встановлення відповідних датчиків тиску і температури. Певні труднощі властиві також методу оцінювання ступеня нерівномірності роботи циліндрів, заснованому на визначенні миттєвих значень частоти обертання валу $n_{i}$, що відповідають такту робочого ходу в і-му циліндрі двигуна. Ці труднощі, в першу чергу, пов'язані зі впливом на результат вимірювань крутильних коливань, які виникають при роботі двигуна в його валопроводі.

Аналіз публікацій. Питанням, пов'язаним 3 підвищенням достовірності результатів визначення як загальних, так і часткових діагностичних параметрів присвячені роботи [1-6].

Так, в [1] при використанні в якості загального діагностичного параметра коефіцієнта корисної дії $\eta$ або питомих витрат палива $g$ пропонується враховувати вплив атмосферних умов, а саме атмосферного тиску, температури навколишнього середовища і відносної вологості повітря. Це потрібно здійснювати шляхом приведення результатів визначення індикаторної потужності $N_{i}$ до нормальних атмосферних умов. Крім того, при визначенні потужності механічних втрат пропонується проводити синхронізацію електроагрегата 3 мережею, а потім виключати подачу палива в привідний двигун, переводячи тим самим генератор в режим синхронного електричного двигуна. Виконання зазначених операцій дає підставу стверджувати, що потужність, яка споживається електричним генератором, працюючим як двигун, дорівнює потужності механічних втрат. В [2] для визначення потужності механічних втрат пропонується визначати час зупинки електроагрегата після виключення подачі 
палива. В [7] при визначенні потужності механічних втрат пропонується знаходити рішення диференціального рівняння руху валу двигуна, оскільки, якщо вважати, що механічні втрати, тобто момент опору є постійною величиною і постійною величиною $є$ момент інерції, то визначення часу зупинки дозволить знайти потужність механічних втрат $N_{m}$.

В [3-6] наводяться рекомендації, використання яких дозволить підвищити достовірність результатів вимірювання таких діагностичних параметрів як тиск газів $P_{2}$ та їх температури $T_{2}$. В [7] вказується, що більш точний результат діагностування технічного стану окремих циліндрів може бути отриманий в випадку, коли в якості діагностичного параметру використовувати ступінь нерівномірності частоти обертання валу $\delta$, визначаєму як відношення різниці між максимальним $\omega_{\max }$ і мінімальним $\omega_{\min }$ значенням кутової частоти обертання до середнього значення $\omega_{c}$ кутової частоти обертання, тобто

$$
\delta=\frac{\omega_{\max }-\omega_{\min }}{\omega_{c}} .
$$

Разом $з$ тим, в [7] вказано застереження про те, що при користуванні цим показником обов'язково слід враховувати крутильні коливання валу, котрі викликають неоднозначність результатів визначення кутів повороту валу. При цьому в [7] та і в інших роботах по розглядаємій тематиці не вказано як саме слід враховувати вплив крутильних коливань валу двигуна. Таким чином, зрозуміло, що підвищити достовірність результатів оцінювання технічного стану окремих циліндрів багатоциліндрового дизельного або бензинового двигуна можливо шляхом уточнення результатів визначення ступеня нерівномірності частоти обертання валу, враховуючи при цьому коливання пружної системи, що утворена колінчатим валом і циліндро-поршневою групою, в якої крім обертального руху є поступовий рух

\section{Основна частина}

При використанні непрямого методу оцінювання ступеня нерівномірності роботи циліндрів багатоциліндрового дизельного або бензинового двигуна шляхом визначення ступеня нерівномірності обертання його вала можливо вимірювати прискорення вала в обмеженому діапазоні кутів його повороту, вимірювати прискорення вала при його прокручуванні й в режимах зміни частоти обертання (зростання частоти обертання валу або ії зменшення при гальмуванні). Результат може бути досягнутий при вимірюванні часу і шляху розгону в діапазоні заданих частот обертання або визначенням поточного значення кутової частоти обертання й різниці між максимальним і мінімальним значеннями кутової частоти та встановленням допустимої границі цієї різниці. Загальним недоліком перерахованих способів визначення нерівномірності обертання валу $є$ необхідність виконання зазначених вимірювань в спеціально організованих режимах роботи елект- роагрегатів,що не завжди можливо в умовах їх експлуатації в системах електропостачання комплексів озброєння і військової техніки [8-9].

Більш зручніше проводити діагностування електроагрегатів в звичайних експлуатаційних режимах їх роботи під навантаженням. Авторами в [10] запропонований спосіб вимірювання ступеня нерівномірності частоти обертання валу, заснований на вимірюванні тривалості відрізків часу повороту колінчатого валу на заданий кут, що дорівнює куту між черговими спалахами в сусідніх за порядком роботи циліндрах двигуна, враховуючи при цьому можливість зміни кутової частоти обертання валу, тобто враховуючи його прискорення. Оскільки значення миттєвої кутової частоти ковзання, які відповідають робочому руху поршня в тому чи іншому циліндрі, неоднакові в зв'язку з тим, що потужністі, які розвиваються циліндрами, неоднакові, оскільки час повороту вала $t_{i}$ на кут, що дорівнює куту між спалахами в сусідніх циліндрах $\phi_{c n л}$, буде неоднаковим, тобто

$$
t_{i}=\frac{\phi_{c n л}}{\omega_{i}}
$$

Якщо вимірювати час $t_{i}$ шляхом підрахунку кількості імпульсів $n_{i}$, що надходять за час $t_{i} 3$ виходу генератора імпульсів, частота якого $f_{2}$ стабільна, то величина $n_{i}$ буде дорівнювати

$$
n_{i}=\frac{t_{i}}{T_{2}}=\frac{\phi_{\text {спл }} f_{2}}{\omega_{i}}
$$

де $T_{2}$ - період слідування імпульсів з виходу генератора імпульсів.

При порівнянні величин $n_{i}$ та $n_{i+1}$ в відповідності до порядка роботи циліндрів визначається величина відносного ступеня нерівномірності частоти обертання валу $\bar{\delta}$

$$
\bar{\delta}=n_{i}-n_{i+1}=\frac{\phi_{\text {сnл }} f_{2}\left(\omega_{i+1}-\omega_{i}\right)}{\omega_{i+1}-\omega_{i}} .
$$

Запропонований спосіб визначення ступеня нерівномірності частоти обертання валу може бути використаний в випадку, коли вимірювання виконують при послідовному відключенні одного з циліндрів двигуна.

Зазначене вимірювання виконують для одного виключеного циліндра і решти працюючих від моменту часу, що відповідає положенню колінчатого вала в верхній мертвій точці в такту стискування на кутовому інтервалі, який дорівнює куту між черговими спалахами.

Потім знаходять величину збільшення тривалості цикла при виключеному циліндрі у порівнянні $з$ середньою тривалістю робочого циклу при всіх включених циліндрах.

По результатах порівняння можна зробити висновок щодо технічного стану циліндрів та встановити, що циліндр є несправним у випадку, коли три- 
валість циклу збільшилась на час, який менше середньої тривалості циклу $t_{c p}$, зменшеної в

$$
(i-1)\left(1+\delta_{\partial o n}\right) \text { раз }
$$

де i - кількість циліндрів; $\delta_{\text {доп }}$ - ступінь нерівномірності в відносних одиницях, яка вважається допустимою для даного типу двигуна.

Вибір величини

$$
\frac{t_{c p}}{(i-1)\left(1+\delta_{\partial o n}\right)}
$$

в якості міри для оцінювання технічного стану двигуна пояснюється наступними міркуваннями. У випадку, коли всі циліндри знаходяться в працездатному стані і їх внесок в роботу двигуна однаковий, тривалість $t_{1}$ цикла в циліндрі при одному виключеному циліндрі визначається таким чином

$$
t_{1}=\frac{i}{i-1} t_{c p}
$$

а збільшення тривалості циклу $\Delta t_{i}$ визначається як

$$
\Delta t_{i}=t_{1 i}-t_{c p}=\frac{t_{c p}}{i-1} .
$$

Діючи державні стандарти допускають можливість нерівномірності роботи окремих циліндрів двигуна, що дає підстави внести в співвідношення (12) поправку, яка враховує допустиму ступінь нерівномірності $\delta_{\text {доn }}$, і вважати, що в випадку коли

$$
\Delta t_{i} \angle \frac{t_{c p}}{(i-1)\left(1+\delta_{\partial o n}\right)} .
$$

і-циліндр розвиває недопустимо малу потужність та його слід вважати несправним.

Суттєвим недоліком розглянутих способів визначення ступеня нерівномірності частоти обертання валу є низька достовірність результатів вимірювання часу повороту валу на кут, що дорівнює куту між спалахами в сусідніх за порядком роботи циліндрах двигуна. Це пов'язано з тим, що для виконання вимірювань пристрої діагностики обладнують датчиками положення колінчатого вала [11-12], на роботу яких впливають крутильні коливання, які виникають в пружній системі « колінчатий вал - циліндро-поршнева група». В результаті в процесі вимірювань відбувається вимірювання не часу повороту вала на кут $\phi_{c n л}$ між спалахами в сусідніх за порядком роботи циліндрів, а час повороту валу на кут

$$
\phi_{\text {спл }} \pm \Delta \phi,
$$

де $\Delta \phi$ - кут закручування валу. Не врахування крутильних коливань знижує достовірність оцінки технічного стану окремих циліндрів дизельних та бензинових двигунів. Для подолання цього недоліку в [10] пропонується здійснювати вимірювання часу повороту вала на зазначений кут зі змінним масштабом часу, використовуючи для цього керуємий генератор імпу- льсів, частота слідування імпульсів на виході якого залежить від значення керуючої напруги, яка подається на вхід керуємого генератора імпульсів і визначається поточним значенням кута закручування $\Delta \phi$, який вимірюється датчиком крутильних коливань [13-17]. При цьому для забезпечення вимагаємої роботи пристрою діагностики пропонується використовувати в його складі систему фазового автоматичного підстроювання частоти, яка складається 3 фазового детектора, фільтра нижніх частот та керуємого генератора імпульсів. Фазовий детектор [18-19] пропонується виконати на базі асинхронного RS-тригера, на $\mathrm{S}$-вхід якого подаються вихідні сигнали формувача імпульсів. Імпульсна послідовність, що слідує з виходу формувала імпульсів з частотою $\omega_{1}$, визначається вимірювальним перетворювачем положення валу двигуна. Часові інтервали між імпульсами при нерівномірності роботи циліндрів двигуна є неоднаковими. Ha R-вхід RS-тригера поступають сигнали з виходу керуємого генератора імпульсів, частота $\omega_{0}$ яких, при відсутності керуючого сигналу з фільтра низьких частот, $є$ свідома меншою номінальної частоти обертання двигуна $\omega_{\text {ном }}$.

Тривалість сигналу високого рівня на прямому виході RS - тригера , визначається фазовим зсувом між імпульсними послідовностями 3 виходу формувала імпульсів та 3 виходу керуємого генератора імпульсів, й залежність від початкової різниці частот $\omega_{1}$ та $\omega_{0}$.

Напруга 3 виходу RS- тригера через фільтр нижніх частот подається до входу керуємого генератора імпульсів. При цьому відбувається автоматичне підстроювання частоти $\omega_{0}$ керуємого генератора імпульсів до частоти $\omega_{1}$. Імпульсна послідовність 3 виходу керуємого генератора імпульсів зсунута по фазі в бік відставання на кут $\beta$, який пропорційний початковій різниці частот $\omega_{1}$ та $\omega_{0}$. В свою чергу, величина кута зсуву фаз $\beta$ пропорційна напрузі, яка необхідна для підстроювання частоти керуємого генератора імпульсів $\omega_{0}$ до значення $\omega_{1}$. Величина кута зсуву фаз $\beta$ використовується в подальшому для визначення нерівномірності частоти обертання вала двигуна. Для цього на інтервалі часу, що відповідає кутовому відрізку $\beta$, підраховується кількість імпульсів $n_{i}$, які подаються $з$ виходу керуємого генератора імпульсів високої частоти $f_{2}$, частота якого залежить від крутильних коливань. Підрахунок кількості імпульсів $n_{i}$ здійснюється в реверсивному лічильнику імпульсів. На кутовому відрізку $\beta_{i+1}$ відбувається зчитування кількості імпульсів $n_{i+1}$, яке записано в реверсивному лічильнику імпульсів. Кількість імпульсів, що залишилась в реверсивному лічильнику імпульсів пропорційна величині нерівномірності частоти обертання вала $\delta$.

Більш вдалий варіант врахування впливу крутильних коливань на результат визначення ступеня 
нерівномірності частоти обертання вала двигуна запропонований в [20]. В цьому пристрої для врахування впливу крутильних коливань на визначення моментів початку та закінчення процесів вимірювання відрізків часу, які визначають такт робочого ходу ( розширення) в тому чи іншому циліндрі двигуна, крім датчика положення колінчатого вала, формувача імпульсів, RS-тригера, фільтра нижніх частот, керуємого генератора імпульсів, генератора імпульсів високої частоти й реверсивних лічильників імпульсів, пропонується ввести датчик циклів, в якості якого використовується індикатор моменту вприскування палива в перший, за порядком роботи, циліндр двигуна та датчики верхньої мертвої точки поршня для кожного 3 циліндрів двигуна. Введені додаткові елементи дозволяють здійснювати корекцію результатів підрахунку кількості імпульсів $n_{i}$ за час повороту вала на кут, що визначається при зміні положення колінчатого вала.

У випадку, коли сигнал на виході датчика верхньої мертвої точки поршня з'являється пізніше ніж сигнал на виході датчика положення вала двигуна у реверсивному лічильнику імпульсів здійснюється додавання до кількості імпульсів, записаних у цьому лічильнику на кутовому інтервалі, що визначається часом між появою сигналу від датчика положення колінчатого вала і від датчика верхньої мертвої точки в першому циліндрі двигуна.

У випадку, коли сигнал на виході датчика верхньої мертвої точки поршня з'являється раніше ніж сигнал на виході датчика положення колінчатого вала здійснюється віднімання в реверсивному лічильнику імпульсів кількості імпульсів, яка визначається часом між появою сигналу від датчика верхньої мертвої точки поршня в першому за порядком роботи циліндрі та появою сигналу від датчика положення колінчатого вала.

\section{Висновки}

1. При оцінюванні технічного стану дизельних та бензинових двигунів електроагрегатів військових електростанцій їх загальний технічний стан необхідно визначати, використовуючи для цього в якості діагностичного параметру коефіцієнт корисної дії електроагрегата або питомі втрати палива.

2. Для підвищення достовірності результатів діагностування загального технічного стану пропонується враховувати вплив на результати вимірювань атмосферних умов та механічні втрати, способи визначення яких наводяться.

3. При оцінюванні технічного стану окремих циліндрів дизельного або бензинового двигуна слід використовувати в якості діагностичного показника ступінь нерівномірності частоти обертання його вала.

4. Для підвищення достовірності результатів технічного діагностування дизельних та бензинових двигунів військових електроагрегатів шляхом визначення ступеня нерівномірності частоти обертання його вала обов'язково слід враховувати вплив крутильних коливань на результати вимірювань.

5. Дієвим засобом врахування крутильних коливань пружної системи «колінчатий вал - циліндро-поршнева група» при визначенні ступеня нерівномірності частоти обертання вала є використання змінної частоти генерування імпульсів, за допомогою яких здійснюють визначення часу повороту вала на зазначений кут, або визначення кута між спалахами в сусідніх за порядком роботи циліндрів за допомогою індикатора моменту вприскування палива в циліндр двигуна та датчика верхньої мертвої точки.

\section{СПИСОК ЛІТЕРАТУРИ}

1. Диагностика и техническое обслуживание машин.: учебник для студентов высших учебных заведений / [Ананьин А.Д., Михлин В.М., Габитов И.И. и др.].-М. : Издательский центр "Академия", 2008.— 432 с.

2. Губертус Гюнтер Диагностика дизельных двигателей. Серия "Автомеханик". Пер. с нем. Ю.Г. Грудского.—М.: ЗАО "КЖИ За рулем", 2004.- 176 с. ил.

3. Мигаль В.Д. Техническая диагностика автомобилей. Теоретические основы.: учебн. пособие/ В. Д. Мигаль.- Х.: "Майдан", 2014.-516 с.

4. Чарльз Уайт. Диагностика двигателя. Коды неисправностей: Руководство. Издательство: Алфамер Паблишинг ЗАО, 2003.-256 c.

5. Биргер И. А. Техническая диагностика / И. А. Биргер. - М. : Машиностроение, 1978. - 239 с. - (Надежность и качество. Межиздат. сер.).

6. Мислович М. В. Про деякі особливості побудови інтелектуальних багаторівневих систем технічної діагносики електроенергетичних об`єктів / М. В. Мислович, Р. К. Сисак // Техн. електродинаміка. - 2015. - № 1. - С. 78-85. Бібліогр.: 9 назв.

7. Кононов Б.Т. Вибір показника для оцінювання технічного стану дизель-генератора / Б.Т. Кононов, О.І. Бондаренко // Збірник наукових праць Харківського національного університету Повітряних Сил. - 2017. - № 3(52). - С. 113117.

8. Техническая диагностика / И. М. Синдеев [и др.] ; под общ. ред В. В. Клюева, И. П. Пархоменко. - М. : Машиностроение, 1987. - 351 с.

9. Поляков А. П. Обгрунтування критеріїв оцінки впливу удосконаленої системи діагностування на ефективність використання транспортних засобів / А. П. Поляков, О. З. Горбай, М. Ю. Миронюк // Вісн. машинобуд. та транспорту. 2016. - № 2. - C. 77-81.

10. АС СССР №1469384 Способ определения технического состояния двигателя внутреннего сгорания./ Н.И Григоров, М.И. Загороднев, Б.Т.Кононов, В.З. Ройк, Б.Ф. Самойленко, К.Г.Сергеев, Ю.И.Стрелков. Заявлено 20.08.1987, опубл. 30.03.1989, бюл.№12. 
11. Мигаль В.Д. Системы диагностирования автомобиля:учебник / В.Д. Мигаль. —Х.: Майдан, 2017.—592 с.

12. Загальні принципи діагностування електронних систем керування автомобіля: навч. Посібник / О.Ф.Дащенко, В.Г. Максимов, О.Д.Ніцкевич та ін.. За ред.. М.Б.Копитчука . Одеса: Наука і техніка, 2012.—392 с.

13. Серридж М. Пьезоэлектрические акселерометры и предусилители: справочник по теории эксплуатации / М. Серридж. Т. Р. Лихт.- Дания. Брюль и Кьер, 1987.-186 с.

14. Панфилов Д.Н. Датчики фирмы Motorola/ Д.Н.Панфилов, В.С. Иванов.-М.: ДОДЭКА,2000.-96 c.

15. Джексон Р.Г. Новейшие датчики/ Р.Г.Джексон.- М.: Техносфера,2007.-384 с.

16. Фрайден Дж. Современные датчики. Справочник / Дж. Фрайден.-М.: Техносфера, 2005.—592 с.

17. Литвиненко В.В. Автомобильные датчики, реле и переключатели / В.В. Литвиненко, А.П. Майструк.-М.:ЗАО КЖИ “За рулем", 2004.-176 с.

18. Смирнов Ю.А. Электронные и микропроцессорные системы управления автомобилей: учеб. пособие / Ю.А. Смирнов, А.В. Мухаванов.- СПб.: Изд-во “Лань”, 2012.-612 с.

19. Сашко В.А. Електронне та електричне обладнання автомобілів / В.А. Сашко.—К.: Каравела, 2007.—367 с.

20. Патент України на корисну модель № 126897. Пристрій для оцінювання нерівномірності роботи циліндрів двигуна внутрішнього згоряння/ Б.Т. Кононов, О.А.Кононова, А.О.Нечаус, О.О. Ручка, В.М. Уваров. Заявлено 01.02.2018, опубл. 10.07.2018, бюл.№13.

Рецензент: д-р техн. наук, проф. Б. Г. Любарський, Національний технічний університет "ХПГ”, Харків

Received 12.07.2018

Accepted for publication 12.09.2018

\title{
Пути повышения достоверности оценивания технического состояния отдельных цилиндров многоцилиндровых дизельных и бензиновых двигателей
}

\author{
Б. Т. Кононов, Ю. Д. Мусаирова
}

Приводятся рекомендации насчет повышения достоверности оценивания общего технического состояния дизельных и бензиновых двигателей внутреннего сгорания электроагрегатов военных электростанций при использовании в качестве диагностического параметры коэффициента полезного действия или удельного расхода топлива. Основное внимание уделяется способам оценивания технического состояния отдельных цилиндров многоцилиндровых двигателей. Предлагается при оценивании степени неравномерности работы цилиндров двигателя в качестве диагностического параметра использовать степень неравномерности угловой частоты вращения его вала. Объясняется, как следует измерять эту величину, указывается что на достоверность результатов измерений влияют крутильные колебания упругой системы “коленчатый вал - цилиндро-поршневая группа". Приводятся варианты технических решений, использование которых позволит устранить влияние крутильных колебаний на результаты диагностирования. Определено, что действенным средством учета крутильных колебаний упругой системы «коленчатый вал - цилиндро-поршневая группа» при определении степени неравномерности частоты вращения вала является использование переменной частоты генерации импульсов, с помощью которых осуществляют определение времени поворота вала на указанный угол, или определение угла между вспышками в соседних с порядком работы цилиндров с помощью индикатора момента впрыска топлива в цилиндр двигателя и датчика верхней мертвой точки.

Ключевые слова: диагностические параметры для оценивания общего технического состояния двигателя и оценивания технического состояния отдельных цилиндров, степень неравномерности частоты вращения вала, крутильные колебания и их влияние на результаты определения степени неравномерности работы отдельных цилиндров.

\section{Ways of increase in reliability of estimation of technical condition of separate cylinders of multicylinder diesel and petrol engines}

\section{B. Kononov, Yu. Musairova}

Studying subject in article is possible ways of increase in reliability of estimation of technical condition of separate cylinders of multicylinder diesel and petrol engines. Degree of reliability of determination of the valid technical condition of military power plant depends on that as fully controlled parameters reflect actual state of a subject to control. Recommendations about increase in reliability of estimation of the general technical condition of diesel and petrol internal combustion engines of electrical units of military power plants when using as diagnostic parameters of efficiency or specific fuel consumption are provided. The main attention is paid to ways of estimation of technical condition of separate cylinders of multicylinder engines. It is offered at estimation of degree of unevenness of operation of cylinders of the engine as diagnostic parameter to use degree of unevenness of angular frequency of rotation of his shaft. Speaks properly to measure this size, it is specified that the reliability of results of measurements is influenced by tortional fluctuations of the elastic system "cranked shaft-tsilindro-piston group". Also for increase in reliability of results of diagnosing it is offered to consider influence of atmospheric conditions, such as atmospheric pressure, ambient temperature and relative humidity of air and also mechanical losses. Options of technical solutions which use will allow to eliminate influence of tortional fluctuations on results of diagnosing are given in article. It is determined that the effective means of taking into account torsional oscillations of the elastic system "crankshaft - cylinder-piston group" in determining the degree of unevenness of the rotational speed of a shaft is the use of a variable pulse generating frequency, by which they determine the rotational time of a shaft at a given angle, or determine the angle between flashes in adjacent cylinders with the help of an indicator of the moment of fuel injection into the engine cylinder and the sensor of the upper dead center.

Keywords: diagnostic parameters for estimation of the general technical condition of the engine and estimation of technical condition of separate cylinders, degree of unevenness of frequency of rotation of a shaft, tortional fluctuations and their influence on results of definition of degree of unevenness of operation of separate cylinders. 